\title{
Brexit from the Perspective of EU Sovereignty. Some Comments on Tom Eijsbouts' Contribution to this Book
}

\author{
Ana Maria Guerra Martins
}

\section{Abstract}

The author argues that the application of the idea of sovereignty to the EU can bring fears and suspicions that must be avoided in the current European context. Otherwise, by definition, the idea of sovereignty comprises an element of exclusivity, which is almost impossible to spread over more than one entity. Sharing sovereignty is to some extent a contradictory idea. The author also sustains that the presidency of the euro summit must be assessed in the context of EMU governance, and within this broader context, this is anything but an exercise of EU's sovereignty. In addition, Article $50 \mathrm{TEU}$ does not express some kind of EU sovereignty, as the case Wightman of the Court of Justice recently confirmed. Even if all these difficulties could be overcome, it remains the question whether the idea of EU sovereignty can be helpful after the withdrawal of the United Kingdom. In the view of the author, it cannot, and all in all, the EU does not need to be compromised with sovereignty.

\section{A Challenging and Inspiring Contribution but...}

Commenting Tom Eijsbouts' contribution in this book is a rather challenging task because he introduced in the discussion of Brexit one of the most traditional notions that has ever been conceived in philosophy, political science and legal theory - the idea of sovereignty. Fascinated by the discourse of the President Macron of 26 September 2017 at Sorbonne, ${ }^{1}$ Tom Eijsbouts seeks to give new clothes to the concept of sovereignty, rejecting the perspective of those who consider that the idea of sovereignty is nowadays outdated.

1 Available at http://www.elysee.fr/declarations/article/initiative-pour-l-europe-discou rs-d-emmanuel-macron-pour-une-europe-souveraine-unie-democratique/. 
By contrast, he accepts that Brexit is an exercise of UK sovereignty, underlining, at the same time, that 'Brexit proves that the UK's sovereignty has failed to evolve with its membership to EU and take on a European dimension'.

For Tom Eijsbouts, at the end of the day, the Brexit decision may be explained by the failure of realizing the European dimension of sovereignty.

Apparently, for him, once sovereignty means authority, a multilevel constitutionalism must be based on some kind of multilevel sovereignty in progress that is located together in the individual Member State and in the Member States altogether as well as in the European Union.

According to Tom Eijsbouts, in order to prevent events, such as Brexit, Europe needs to build up its own sovereignty, which shall be added to the States' sovereignty. For him, the way how the Euro summit came into being and got itself a permanent president shall be faced as an exercise of European sovereignty.

This is a rather inspiring and innovative perspective. However, as fascinating as it may be, the transposition of the idea of sovereignty into the European Union will, in my opinion, face some insurmountable obstacles.

Firstly, applying the idea of sovereignty to the EU is a risky adventure, once it can bring more problems than contribute to solve whatever it is. From the outset, it can arouse fears and suspicions that must be avoided in the current European context at all costs. All in all, the EU does not need to be compromised with sovereignty.

Secondly, the definition of EU sovereignty is anything but simple, once it must integrate and respect the sovereignty of the Member States. Or, by definition, the idea of sovereignty comprises an element of exclusivity, which is almost impossible to spread over more than one entity. The idea of shared sovereignty, which has already been rather popular among the legal scholarship, is to some extent contradictory.

Thirdly, the presidency of the euro summit must be assessed in the context of EMU governance. Within this broader context, one can hardly accept that it was an exercise of EU sovereignty.

Fourthly, Article 50 TEU might comprise some elements that go beyond the classical idea of sovereignty but that does not mean that they express some kind of EU sovereignty. The recent decision of the Court of Justice, ${ }^{2}$ accepting the reversibility of the notification of leaving the EU confirms that the UK sovereignty is much more powerful. 
Fifthly, even if all these difficulties could be overcome, it remains the question whether the idea of EU sovereignty can be helpful after the withdrawal of the United Kingdom.

In the following pages I will elaborate on these topics.

\section{Sovereignty of the European Union - a Risky Adventure?}

\subsection{Inseparable link between sovereignty and State}

Starting by clarifying why the application of the concept of sovereignty to the European Union, is, in my point of view, a risky adventure, I would say that the idea of sovereignty was not conceived for a multilevel constitutional ${ }^{3}$ and political entity, ${ }^{4}$ such as the EU.

Conversely, it was conceived by Jean Bodin, ${ }^{5}$ in the sixteenth century, intrinsically linked to the State as an institution that maintains a supreme governing authority over a defined territory and which is to be differentiated both from its constituent people and its office holders. The sovereignty was, in the internal perspective, the absolute and indivisible authority of the ruling power. ${ }^{6}$ This theory was meant to serve a practical political purpose. ${ }^{7}$ In order to survive the State needed to eliminate all other powers.

Secondly, the external dimension of the sovereignty, which implies the capacity of acting within the international community on an equal footing with other States, arose later (nineteenth century).

3 See: Ana Maria Guerra Martins, 'Opinion 2/13 of the Court of Justice in the Context of Multilevel Protection of Fundamental Rights and Multilevel Constitutionalism Revisited', in L Papadopoulou / I Pernice / J. H. H. Weiler (eds.), Legitimacy Issues of the European Union in the Face of Crisis - Dimitris Tsatsos memoriam (BadenBaden, Hart / Nomos, 2017) 233-270, as well as the bibliography therein quoted.

4 I have always argued that the EU is a new form of aggregation of political power. See: Ana Maria Guerra Martins, Manual de Direito da União Europeia (Lisboa, Almedina, 2017) $229 \mathrm{ff}$.

5 J. Bodin, De Republica (1576).

6 Martin Loughlin, 'The erosion of sovereignty' (2016) Netherlands Journal of Legal Philosophy 58.

7 Tina Oršolič Dalessio, 'The issue of sovereignty in an ever closer union' (2014) Croatian Yearbook of European Law and Policy 69. 
However, both dimensions were born and grew up with in the scope of the State, ${ }^{8}$ whose affirmation as a political entity required a strong internal and external authority. To put it in other words, the idea of sovereignty arose in a very particular environment and enjoyed certain unrepeatable circumstances. That means the idea of sovereignty was - as many other ideas - a product of a certain time and a certain place.

As the circumstances have changed, so has the understanding of sovereignty. ${ }^{9}$ In continental Europe it took the form of popular sovereignty, while in Great Britain it was transformed into the principle of parliamentary sovereignty. ${ }^{10}$

\subsection{The EU's challenges to the idea of sovereignty}

The project of the European integration has also created great challenges to the idea of sovereignty. ${ }^{11}$ However, in my opinion, any attempt to transpose this idea into the European Union itself is at first starved for failure.

The European Union is a compound entity, created by the Member States, and its authority derives, firstly, from them and, secondly, from the citizens.

The European Union was made neither to - and it actually cannot eliminate the authority of the Member States nor to replace them. By contrast, it comprises the Member States and it is founded on cooperation, mutual influence, reciprocal confidence and interdependence.

In my opinion, the inclusion of the idea of sovereignty in this context may jeopardize the relationship between the Union and the Member

8 On the concept of sovereignty and its evolution see Daniel Philpott, "Ideas and Evolution of Sovereignty", Sohail H. Hashmi (ed.), State Sovereignty: Change and Persistence in International Relations (Pennsylvania State Univ. Press, 1997) $15 \mathrm{ff}$; Bruno De Witte, 'Sovereignty and European Integration: the Weight of Legal Tradition' (1995), MJ 145 ff; Joseph A. Camilleri/Jim Falk, The End of Sovereignty? The Politics of a Schrinking and Fragmenting World (Edward Elgar Publishing,1992) 1168; R.P. Anand, 'Sovereign Equality of States in International Law', Recueil des Cours de l'Académie de Droit International 197 (1986, II), 17-46.

9 Tina Oršolič Dalessio, (2014) 'The issue of sovereignty' 69.

10 This is not the adequate place to elaborate on these topics. In order to go further see Neil Walker, 'Sovereignty Frames and Sovereignty Claim', Research Paper Series No 2013/14 of the School of Law of the University of Edinburgh, $4 \mathrm{ff}$; Pavlos Eleftheriadis, "Law and Sovereignty" Legal Research Paper Series No 42/2009.

11 See, above all, Neil MacCormick, 'Beyond the Sovereign State' (1993) Modern Law Review, 1-18. 
States' institutions, as even may break the mutual confidence and cooperation between the Member States and the EU.

The assertion of sovereignty by the EU would certainly provoke an affirmation of sovereignty by the side of the Member States. Actually, throughout the history of the European integration, there are many examples of tension between the Member States and the European Union, due to disputes on sovereignty, as the case law of some Supreme ${ }^{12}$ and Constitutional Courts ${ }^{13}$ has ever shown. In their Lisbon Treaty judgements some Constitutional Courts ${ }^{14}$ seemed to be more flexible as regards the understanding of sovereignty. However, all courts 'have made it clear that the process of European integration can only go on as far as it does not infringe upon the core national sovereign powers'. ${ }^{15}$

If one introduces the sovereignty narrative in the European Union, one can easily anticipate the raising of tensions between the Member States and the EU institutions.

The idea of sovereignty of the Union would also comprise an internal and an external authority, which could compete with the authority of the Member States. This competition would certainly provoke a permanent tension between the institutions of the European Union and the Member States that would not be beneficial for the future developments of the relationship between the EU and the Member States.

Therefore, I do not believe that the notion of sovereignty would be very helpful in the context of the European Union.

As regards the external dimension of the EU, it is even more questionable to accommodate the idea of sovereignty. Although the Union has the capacity to act at the international level, it is subjected to several restraints. The conclusion of mixed agreements, ${ }^{16}$ the limited competence in the field of foreign security and defense policies ${ }^{17}$ are only two examples of these restrictions. However, they illustrate rather well that the lack of EU's author-

12 See, for instance, the Irish Supreme Court in the judgement Crotty $v$ An Taoiseach or the Danish Supreme Court Decision in the Maastricht case.

13 See the French Constitutional Council in the Maastricht case I, the German Federal Constitutional Court in the Maastricht case, the Spanish Constitutional Court in the Decision on the Treaty establishing a Constitution for Europe.

14 See the decisions of Lisbon Treaty of the German Federal Constitutional Court, the Czech Constitutional Court, the Hungarian Constitutional Court, the Latvian Constitutional Court and the Polish Constitutional Court.

15 Tina Oršolič Dalessio, 'The issue of sovereignty', 77.

16 Ana Maria Guerra Martins, Os desafios contemporâneos à ação externa da União Europeia - Lições de direito internacional público II (Coimbra, Almedina 2018) $211 \mathrm{ff.}$

17 Ana Maria Guerra Martins, Os desafios contemporâneos, $320 \mathrm{ff}$. 
ity within the scope of some external fields. Dealing with the concept of sovereignty in this context is problematic.

Additionally, in several domains the core of international political authority still belongs to the Member States.

Contrary to Tom Eijsbouts, I do think that the historical background of the idea of sovereignty is so strong that it can hardly be freed from it.

\subsection{The EU Sovereignty Idea May Cause More Damages than Gains}

In my point of view the introduction of the idea of sovereignty in the European Union discourse may cause more damages than gains, once it may lead to some misunderstandings, turmoil and even may reactivate nonsense fears, which is the most propitious terrain for evolving Eurosceptic, nationalist and populist movements.

In my opinion, as the European Union has become a different and unique political entity in the world, the use of old notions, such as sovereignty or federalism, in legal and political theories may well result in more problems than solve whatever it is.

In its origins, the idea of sovereignty contains not only an element of authority but also a component of exclusivity. It is rather difficult for the Member States and, who knows, even for the citizens to accept some kind of multilevel sovereignty in progress that is located either in the individual Member State or in the Member States altogether or in the European Union.

I do believe that it is better to replace or even to abandon the idea of sovereignty, ${ }^{18}$ which is too connected to the State, than seeking to adapt it to political entities that have nothing to do with the State and I am not alone in this belief. ${ }^{19}$

In my view, the introduction of the idea of sovereignty into the narrative of the European Union can only contribute to exacerbate the current internal tension between the Member States and the EU institutions. And Brexit is a good example of how the introduction of the idea of sovereignty in the European Union discourse may well lead to negative Member States' reactions.

18 Against: Bruno De Witte, 'Sovereignty and European Integration' 172-173.

19 See: Pavlos Eleftheriadis, 'Law and Sovereignty', maxime 37-39. Michael Newman, Democracy, Sovereignty and the European Union (London, St. Martin's Press, 1996), 12; Michel Leroy, 'Requiem pour la souveraineté, anacronisme pernicieux', in Mélanges offerts à Jean Vélu, tome I, (Brussels, Bruylant, 1992), $91 \mathrm{f}$. 
It is never too much to remember that Brexit relied on the rhetoric of State sovereignty before and after the referendum of 23 June 2016.

'Taking back control' over laws, borders, democracy, and money means nothing but 'taking back control' over the most significant issues of the State sovereignty and its constitutional system.

Notwithstanding, the rhetoric of sovereignty does not take many factors into account. Firstly, the effects of the withdrawal of a Member State are not restricted to the Member State that leaves the EU, but they are also felt in the other Member States. That means the sovereignty of the remaining Member States is also threatened. Secondly, it is true that the referendum is one means to express the will of the people, but it is not the sole legitimate tool in the context of the exercise of democracy. To put it bluntly, sometimes it is not the most accurate one, especially when nobody seriously considered the consequences of a negative result. Many scholars, including in the UK, criticized the political decision of launching a referendum on the exit of the EU. For instance, Jo Shaw drew attention to the particularities of the UK as a Union State and to the fact that some voices were not heard in the referendum vote and that those voices were also neglected during the debate that preceded the referendum. ${ }^{20}$

In the perspective of the remaining Member States, the withdrawal may be conceived as an "authoritarian" decision, since their citizens will lose certain rights - for instance, the ones inherent to EU citizenship - without having been consulted.

Accepting that Brexit is an expression of the UK sovereignty- which is rather consensual and recently confirmed by the Court of Justice of the $\mathrm{EU}^{21}$ - implies at the same time the rejection of EU sovereignty.

Therefore, if one does not want to introduce more sand into the gear, it is better to leave some words, such as sovereignty or federalism, where they are - within the State. That means aside the EU.

\subsection{Other difficulties Raised by the Extension of the Concept of Sovereignty}

Extending the concept of sovereignty beyond the State raises other questions, such as the one of its scope of application. Is it reduced to the EU or

20 V. Jo Shaw, "The quintessentially democratic act? Democracy, political community and citizenship in and after the UK's referendum of June 2016" (2017) Journal of European Integration, 12.

21 CJEU, C-621/18 Wightman and Others ECLI:EU:C:2018:999. 
is the idea of sovereignty potentially applicable to every political entity? Is it applicable to the international community in general, namely, to international organizations? Is it applicable to global governance, which comprises all sorts of actors (either public authorities or private)?

I am not saying that Tom Eijsbouts suggested going that far. Actually, I do not think so. However, if one opens the Pandora's box of the sovereignty beyond the State, one must be ready to extend it, at least, to some international organizations, such as United Nations or the Council of Europe.

In my view, if the application of the idea of sovereignty to the EU raises enormous problems, extending the said application to international organizations, which are dominated by the Member States, will face even greater obstacles. And the sovereignty of the global governance is even more unconceivable. This is true that global governance includes informal entities that exercise authority without clear legal and political limits and sometimes against the decisions of the States and of other legitimated international actors, such as the international organizations. However, that does not mean they are exercising sovereignty. By contrast, such situations only highlight the difficulties of drawing a clear boundary between the exercise of sovereignty and a pure exercise of power (force). Not all acts originating from a political authority should be regarded as sovereign acts.

In the event that the idea of sovereignty only applies outside the State within the European Union, as it seems to be the reasoning of Tom Eijsbouts, I do not see what is the difference of some well-known concepts, such as 'pooled sovereignty', 'shared sovereignty',22 or 'divided sovereignty', which have been theorized by the EU law scholarship since the very beginning of the European integration.

22 Stefan Oeter, 'Souveränität und Legitimation staatlicher Herrschaft im europäischen Mehrebenesystem', in Astrid Epiney et al, Direkte Demokratie und Europäische Union. Démocratie directe et Union européenne (Freiburg 1998), $29 \mathrm{ff}$; idem, 'Souveränität und Demokratie als Probleme in der "Verfassungsentwicklung" der Europäischen Union' (1995) ZaöRV, 666 ff. 


\section{Denial of EU Sovereignty}

\subsection{The evolution of EMU Governance denies the EU Sovereignty}

Contrary to Tom Eijsbouts, I do not assess the way how the Euro summit of 25 March 2010 in Brussels came into being and got a permanent president as an exercise of European sovereignty.

In my viewpoint, this isolated act should be evaluated in the wider context of the response of the EU and the Member States to the sovereign debt and euro crises. When one puts this act in context, one can hardly accept that the way how the EMU governance evolved during the crisis represents any kind of exercise of EU sovereignty. By contrast, as it is well known, in order to challenge the crisis not only a panoply of legislative measures through the procedures established by the Lisbon Treaty were approved, but also some inter-governmental treaties (the European Stability Mechanism, the Treaty on Stability, Coordination and Governance in the Economic and Monetary Union, the so-called Fiscal Compact, and the Single Resolution Fund in the context of the banking union ${ }^{23}$ ) and the executive agreements (EFSF2 and the Euro Plus Pact). These treaties were approved by the EU Member States outside the Lisbon Treaty and bound only the signatory Member States. As Bruno De Witte put it, 'a group of EU Member States 'stepped outside' the EU legal order and the Union's institutional framework, and instead resorted to instruments of public international law for organizing their cooperation'. ${ }^{24}$

The Euro summit and its presidency are currently enshrined in Article 12 of the Treaty on Stability, Coordination and Governance in the Economic and Monetary Union, the so-called Fiscal Compact, of 2 March 2012, which entered into force on 1 January 2013. The president of the Euro summit is not anymore the President of the European Council, but an elected President. That means the so-called expression of EU sovereignty has suddenly turned into the most evident expression of Member States' sovereignty, since the Fiscal Compact is an international treaty approved and signed by the Member States and not by the EU.

23 On the inter-governmental agreement on the Single Resolution Fund see Federico Fabbrini, 'On Banks, Courts and International Law - the Intergovernmental Agreement on the Single Resolution Fund in Context' (2014) 21 MJ 3, $444 \mathrm{ff}$.

24 Bruno De Witte, 'Using International Law in the Euro Crisis - Causes and Consequences', Working Paper, ARENA Working Paper No. 4, June 2013. 
In the short term the TSCG may be fully integrated into the EU legal framework, following the recommendation of the Five Presidents' report ${ }^{25}$ and a proposal of the Commission of December 2017. ${ }^{26}$ However, up to now the Fiscal Compact remains an exercise of Member States' sovereignty. The EU sovereignty has not been exercised yet.

We will probably need to revisit this topic, if the above mentioned recommendation and proposal become hard law in the future, but with the currently available data, the way how the Euro summit got the permanent presidency was the result of a constellation of factors that cannot be assessed as an exercise of sovereignty.

Anyway, this was not the first time that law was overcome by facts in European integration. The crisis of the chaise vide, the Schengen Agreements, the Social Agreement, the successive opting outs of some Member States are good examples that can be invoked in this context.

To sum up, the way how the Euro summit got the permanent presidency was only a drop in a bucket that does not allow any definitive conclusion. After that episode there were so many manifestations in the opposite direction, which do neither permit to consider that the EU sovereignty has already emerged nor that it is in progress.

\subsection{The reversibility of the $U K$ decision of leaving the $E U$}

Another example that denies the EU sovereignty concerns the reversibility of the UK decision of leaving the EU. This question has been discussed in the academy ${ }^{27}$ since the UK referendum of 23 June 2016.

25 Available at https:/ec.europa.eu/commission/sites/beta-political/files/5-presidentsreport_en.pdf.

26 Proposal of the Commission of 6 December 2017 for a Council Directive laying down provisions for strengthening fiscal responsibility and the medium-term budgetary orientation in the Member States (COM(2017) 824 final 2017/0335 (CNS)). Available at http://eur-lex.europa.eu/legal-content/EN/TXT/PDF/? uri=CELEX:52017PC0824\&from=EN.

27 See 'Editorial Comments' (2016), Common Market Law Review, $1491 \mathrm{ff}$; Christophe Hillion, 'Le retrait de l'Union européenne - une analyse juridique' (2016), Revue trimestrielle de droit européen 719 ff; Paul Craig, 'The Process: Brexit and the Anatomy of Article 50', in Federico Fabbrini (ed.), The Law \& Politics of Brexit (Oxford Univ. Press, 2017) 49 ff; Catherine Barnard, 'Law and Brexit' (2017) Oxford Review of Economic Policy, $4 \mathrm{ff}$; Dora Kostakopoulou, 'Brexit, Voice and Loyalty: Reflections on Article 50 TEU' (2016), European Law Review, $484 \mathrm{ff}$; 
Many scholars have suggested ${ }^{28}$ that the UK decision was not irreversible. According to them, the UK might well change its mind and nothing in Article 50 prohibits the revocation of the notification, as long as it respects the constitutional requirements of the State. As Piet Eeckhout and Eleni Frantziou put it 'if a Member State could not remove its notification after changing its mind, and was thus forced to leave upon the conclusion of a two-year period under Article 50(3), that would effectively amount to an expulsion from the Union - a possibility that was considered and rejected during the travaux. It would also be contrary to the principles of good faith, loyal cooperation, the Union's values, and its commitment to respect the Member States' constitutional identities'. ${ }^{29}$

On 10 December 2018, the Court of Justice of the European Union puts an end to any doubt on this issue. Within the scope of a preliminary ruling request made by decision of the Court of Session, Inner House, First Division (Scotland, United Kingdom), the Court of Justice of the EU ruled that 'Article 50 TEU pursues two objectives, namely, first, enshrining the sovereign right of a Member State to withdraw from the European Union and, secondly, establishing a procedure to enable such a withdrawal to take place in an orderly fashion.' 30

Agreeing with its Advocate General, based on 'the sovereign nature of the right of withdrawal', the Court admitted that 'Article 50(1) TEU supports the conclusion that the Member State concerned has a right to revoke the notification of its intention to withdraw from the European Union, for as long as a withdrawal agreement concluded between the European Union and that Member State has not entered into force or, if no such agreement has been concluded, for as long as the two-year period laid down in Article 50(3) TEU, possibly extended in accordance with that provision, has not expired'. ${ }^{31}$

According to the Court, the reversibility of the notification 'reflects a sovereign decision by that State to retain its status as a Member State of the

Tamara Capeta, 'Brexit and the EU Constitutional Order: A three Act Tragedy' (2016), Croatian Yearbook of European Law and Policy, $1 \mathrm{ff}$.

28 See Paul Craig, 'Brexit: A Drama in Six Acts' (2016), European Law Review, 464465; Piet Eeckhout / Eleni Frantziou, 'Brexit and Article 50 TEU: A Constitutionalist Reading' (December 2016), UCL European Institute Working Paper' 37 ff.

29 Piet Eeckhout / Eleni Frantziou, 'Brexit and Article 50 TEU' 41.

30 CJEU, judgment of 10 December 2018, Wightman and Others, C-621/18, ECLI:EU:C:2018:999, para. 56 and 57.

31 Ibidem, para. 57. 
European Union, a status which is not suspended or altered by that notification $^{32}$ (...), subject only to the provisions of Article 50(4) TEU'. ${ }^{33}$

And the Court stressed that 'given that a State cannot be forced to accede to the European Union against its will, neither can it be forced to withdraw from the European Union against its will'. ${ }^{34}$

The emphasis put on the sovereignty of the Member State by the Court contrasts with the lack of reference to the EU sovereignty. Actually, the EU sovereignty is rather irrelevant in this context.

Having said that, one has to underline that the Court also set up limits to State sovereignty. According to the Court, 'the purpose of that revocation is to confirm the EU membership of the Member State concerned under terms that are unchanged as regards its status as a Member State, and that revocation brings the withdrawal procedure to an end. ${ }^{35}$ That means the revocation of the withdrawal's decision shall not be transformed into a renegotiation of the remaining terms of the Member State in the EU. ${ }^{36}$

In conclusion, the decision of not leaving should be taken, at first instance, by the UK, in accordance with its sovereignty. The EU is, to a certain extent, subjected to that decision, unless it constitutes an abuse of law. ${ }^{37}$

32 See judgment of 19 September 2018, RO, C-327/18 PPU, EU:C:2018:733, paragraph 45 .

33 CJEU, judgment of 10 December 2018, Wightman and Others, C-621/18, ECLI:EU:C:2018:999. para. 59.

34 Ibidem, para. 65.

35 Ibidem, para. 75.

36 For a comment on this decision see Oliver Garner, 'Case C-621/18, Wightman v Secretary of State for Exiting the European Union: the European Court of Justice Confirms that Article 50 Notification can be Unilaterally Revoked' (11 December 2018) European Law Blog available at https:/europeanlawblog.eu/2018/12/11/casec-621-18-wightman-v-secretary-of-state-for-exiting-the-european-union-the-europea n-court-of-justice-confirms-that-article-50-notification-can-be-unilaterally-revoke d/; Dagmar Schiek, "The ECJ's Wightman Ruling, the "Brexit" Process and the EU as a Constitutional Entity" (7.1.2019) Frankfurter Newsletter zum Recht der Europäischen Union, available at https:/www.europa-uni.de/de/forschung/institut/ institut_fireu/newsletter/fireu-Newsletter-34.pdf.

37 Piet Eeckhout / Eleni Frantziou, 'Brexit and Article 50 TEU', 40. 


\section{The Role of Sovereignty within the Negotiations of Brexit}

In spite of the current uncertainty of the Brexit's process, I would shortly like to elaborate on the role played by the idea of sovereignty in the negotiations of Brexit.

Regardless the final result of the Brexit process that nobody can predict by now, the negotiations of Brexit also revealed to some extent a common exercise of Member States' sovereignties.

Firstly, at the very beginning, the rejection of the negotiation strategy of Theresa May, who demanded parallel discussions regarding the withdrawal and trade, illustrates very well the leadership of the Union in the Brexit's process and the common exercise of Member States' sovereignties. According to the President of the European Council, the negotiations should be informed by the following principles: minimization of disruption caused by UK withdrawal; securing agreement on the rights of EU citizens living in the UK; ensuring that the UK honors its financial commitments; and avoiding a hard border between Northern Ireland and Ireland. "These four issues are all part of the first phase of the negotiations. Once, and only once, we have achieved sufficient progress on the withdrawal, can we discuss the framework for our future relationship. Starting parallel talks on all issues at the same time, as suggested by some in the UK, will not happen." 38

The EU's 27 leaders unanimously adopted the phased strategy at the European Council meeting on 29 April 2017. Instead of contributing to divide Member States, Brexit aggregated them around a negotiating strategy that was proposed and supported by the European institutions.

From my point of view, although this decision has a constitutional component and may well be regarded as a constitutional moment, it can hardly be assessed as an exercise of EU sovereignty.

Secondly, the procedure of adoption of the future withdrawal agreement shall also be assessed as a common exercise of the Member States' sovereignties. This agreement shall be concluded on behalf of the Union by the Council, acting by a qualified majority that represents at least $72 \%$ of the members of the Council representing the participating Member States, comprising at least $65 \%$ of the population of these States, after ob-

38 Remarks by President Donald Tusk on the next steps following the UK notification, available at https:/www.consilium.europa.eu/en/press/press-releases/2017/03 /31/tusk-remarks-meeting-muscat-malta/. 
taining the consent of the European Parliament (Articles 50 (2) TEU, 218 (3) and 238 (3) (b) TFEU).

The adoption of the withdrawal agreement by the Council, acting by a qualified majority, could even be seen as a first signal of the exercise of EU external sovereignty. Actually, the withdrawal agreement is concluded between the EU (not by the Member States) and the exiting Member State. However, in my opinion, this is not enough to characterize the treaty-making power of the Union as a pure exercise of sovereignty, due to the composition of the Council. It never acts independently of the Member States collectively. Furthermore, the future withdrawal agreement - if it exists must follow the constitutional requirements of the leaving Member State. Therefore, the successive rejection of the draft agreement by the UK Parliament shows once again the Member State (rectius: the UK) sovereignty prevails.

Thirdly, the recent extension of the 29 March deadline to 31 October 2019, according to Article 50 (3)TEU, may also be assessed as an expression of the common exercise of the 27 Member States sovereignties and the UK sovereignty, once it is taken by a unanimous decision of the European Council and the agreement of the withdrawal Member State.

\section{May EU Sovereignty emerge after Brexit?}

Finally, although it is nowadays impossible to predict whether the exit of the United Kingdom from the Union will contribute to deepen the European integration or will constitute a fertile ground for disintegration, question whether the Brexit can have the effect of launching the EU sovereignty is always possible.

Despite the circulation of some proposals before Brexit, such as the Global Strategy for the European's Union Foreign and Security Policy presented by the High Representative of June 2016, ${ }^{39}$ the Brexit led to the increasing of the discussion of the future of Europe. In March 2017 the Commission launched the White Paper on the Future of Europe, ${ }^{40}$ which did not enclose any concrete proposal but scenarios for discussion. Since then,

39 Available at https:/europa.eu/globalstrategy/sites/globalstrategy/files/regions/files/ eugs_review_web_0.pdf.

40 Available at https://ec.europa.eu/commission/sites/beta-political/files/white_paper _on_the_future_of_europe_en.pdf. 
the debate of the future of Europe has intensively increased both at political and at the academic level.

With or without an agreement concerning the future relationship between the United Kingdom and the EU, the Brexit will without doubt impact in several fields of the Union. For instance, without the UK the institutional framework will not be the same, as it loses one of the biggest Member States. Similar reasoning applies to the financial framework of the Union, once the United Kingdom is a liquid contributor to the EU budget. The impact of Brexit in the EU's Common Foreign and Security Policy (CFSP) and Common Security and Defense Policy (CSDP) will also be remarkable, since the UK is not only the Member State that spends more on security and defense but it is also a Permanent Member of the UN Security Council. ${ }^{41}$ According to Whitman, '...for the EU the loss of UK's diplomatic and military resources will diminish the collective capabilities at the disposal of EU foreign and defence policies', ${ }^{42}$

Depending on the future relationship between the UK and the EU agreement, the impact of UK's exit may still be minimized either for the UK or for the EU.

Let me concentrate on the topic of the rights of EU citizenship and fundamental rights in general. The withdrawal of a Member State - whatever it may be - from the Union will have an impact on EU citizens' rights either they are UK citizens or not. That means the impact of Brexit overcomes the boundaries of the UK. Agreeing with Piet Eeckhout and Eleni Frantziou, 'the withdrawal of a Member State from the European Union creates significant possibilities of regression in terms of fundamental rights, and of panoply of other rights of persons and companies'. ${ }^{43}$

41 On the impact of Brexit into the CFSP see Ramses A. Wessel / Adam Łazowski, 'Legal Consequences of 'Brexit' for the Role of the EU and the UK in Global Affairs', Paper presented at the EUSA Conference, Panel 7 A The Consequences of Brexit on Europe's role: Reinvigoration or Atrophy, Miami, 4-6 May 2017, available at file:///C:/Users/Ana\%20Martins/Downloads/Wessel\%20and\%20Lazowski \%20-\%20Legal\%20Consequences\%20of\%20Brexit\%20-\%20EUSA\%20Miami \%202017\%20-\%20Panel\%207A\%20(1).pdf; James Black et al, Defence and Security after Brexit - Understanding the possible implications of the UK's decision to leave the EU - Compendium Report (Cambridge, Rand Corporation, 2017), $25 \mathrm{ff}$.

42 Richard G. Whitman, "The UK and EU Foreign, Security and Defence Policy After Brexit: Integrated, Associated or Detached?" (2016) National Institute Economic Review, 238-44.

43 Piet Eeckhout / Eleni Frantziou, 'Brexit and Article 50 TEU', 19. 
It is still possible to prevent some consequences of the losing of rights of EU citizenship, ${ }^{44}$ through the conclusion of an international agreement between the UK and the EU, but it is impossible to prevent the losing of rights. This loss does not depend on the exercise of EU sovereignty, rather on the exercise of UK sovereignty, on the one hand, and on the common exercise of Member States' sovereignties within the Union, on the other hand. That means the EU sovereignty does not play any significant role in the future relationship between the UK and the EU.

In addition, there are some fundamental rights that are very difficult to maintain, such as the right to access to the Court of Justice of the European Union either directly or through national courts by means of a reference in the context of a preliminary ruling and the fundamental rights acknowledged by the Charter, which are not part of the ECHR.

Another remark should be made about the EU competences after Brexit.

In my viewpoint, the EU competences will not change as a direct consequence of Brexit. However, after the leave of the UK, it might be easier to exercise some of them ${ }^{45}$ as well as to modify the Treaty, in conformity with Article 48 EU Treaty.

Provided it actually happens, one has to underline that this will not be an exercise of EU sovereignty but an exercise of sovereignty of the Member States, acting collectively.

To conclude, constitutionally speaking, we firmly believe that the EU sovereignty will be a so useless idea after Brexit, as it has been before.

44 See: Guayasén Marrero González, “BREXIT' - Consequences for Citizenship of the Union and Residence Rights', (2016) 23 MJ 5, 796-811; Oliver Garner, 'After Brexit: Protecting European Citizens and Citizenship From 'BREXIT' - Consequences for Citizenship of the Union and Residence Rights', (2016) 23 MJ 5 (2016) 796-811; Oliver Garner, 'After Brexit: Protecting European Citizens and Citizenship From Fragmentation', EUI Working Paper LAW 2016/22.

45 The authors of the Clingendael Report argue that EU defence might well be one of the fields where the exit of the UK may be beneficial. See Anne Bakker / Margriet Drent / Dick Zandee, 'European Defence: how to engage the UK after Brexit?' (The Hague 2017), 8. 